\title{
KSIĘGA AMOSA W INTERPRETACJI PATRYSTYCZNEJ
}

Księga Amosa nie należy do tekstów biblijnych najczęściej komentowanych przez chrześcijańskich pisarzy starożytności i średniowiecza. Jednak niektóre jej wątki, zwłaszcza w interpretacji chrystologicznej, na stałe zadomowiły się w tradycji interpretacyjnej.

Niniejszy artykuł składać się będzie z trzech części. W pierwszej zaprezentujemy greckie i łacińskie komentarze do księgi pochodzące z okresu patrystycznego. Następnie, opierając się na starożytnych i średniowiecznych słownikach symboli biblijnych (Eucheriusza z Lyonu, Pseudo-Melitona i Garniera z Langres), omówimy pokrótce wybrane motywy literackie księgi, które doczekały się rozwinięcia w kluczu symboliki literackiej. Ostatnią część artykułu poświęcimy wersetowi Am 8,11, który najczęściej bywał cytowany w chrześcijańskiej literaturze starożytnej. Ze względu na objętość artykułu ograniczymy się w tym przypadku do chrześcijańskich pisarzy greckich.

\section{Starożytne greckie i lacińskie komentarze do Księgi Amosa}

Komentarze greckie

Teodor z Mopswestil (Commentarius in Amos, PG 66, 241-304)

Komentarz do Dwunastu Proroków Mniejszych powstał wkrótce po napisaniu Komentarza do Psalmów, gdy Teodor nie był jeszcze prezbiterem i miał niewiele ponad 20 lat, a więc wkrótce po $370 \mathrm{r}$., będąc mnichem w klasztorze kierowanym przez Diodora z Tarsu.

W prologu do Komentarza do Księgi Amosa Teodor stwierdza, że proroctwa przeciwko narodom i cierpienia, jakie dotkną Izraela zostały przez Amosa zapowiedziane ,ze względu na Jezusa Chrystusa, który w mającym nadejść czasie przyniesie zbawienie wszystkim ludziom" (prolog, PG 66,141A). 
Jednak w toku komentarza ogranicza się do wymiaru historycznego, bez żadnych odniesień chrystologicznych, cytując wyłącznie Stary Testament (wyjątkiem są 2 cytaty z Dz 7,43; 15,16, które jednak nie wnoszą nic z punktu widzenia teologicznego).

Cyryl Aleksandryjski (PG 71, 407-581)

Komentarz Cyryla do Dwunastu Proroków Mniejszych powstał w okresie jego twórczości egzegetycznej, już jako biskupa Aleksandrii, przed zaangażowaniem się w spory nestoriańskie (przed słynnym listem wielkanocnym z $429 \mathrm{r}$, potępiającym Nestoriusza), przypuszczalnie po Glaphyrach do Pięcioksięgu i po Komentarzu do Izajasza, a więc w latach dwudziestych (420-429). Jest to najobszerniejszy ze wszystkich greckich komentarzy do Amosa, pod wpływem egzegezy aleksandryjskiej.

W krótkim wstępie komentator ogranicza się do wymiaru historycznego, przedstawia głównie dane biograficzne dotyczące życia Amosa, jednak w wyjaśnieniach często odwołuje się do Nowego Testamentu, np.:

- Am 2,8 („Na płaszczach zastawnych wylegują się przy każdym ołtarzu i wino wymuszone grzywną piją w domu swego Boga") odnosi do Mt 21,13 („Napisane jest: Mój dom ma być domem modlitwy, a wy czynicie z niego jaskinię zbójców");

- Potęga Boga z Am 2,9 (,Ja to przed nimi zgładziłem Amorytów, którzy byli wysocy jak cedry, a mocni byli jak dęby. I zniszczyłem owoc ich z góry, a z dołu korzenie") zapowiada Łk 10, 19 (Moc, by deptać po skorpionach) i Ef 6,12 (walka nie z ciałem i krwią, lecz ze złem duchowym).

- Obraz pasterza z Am 3,12 (,Tak jak pasterz z lwiej paszczy ratuje tylko dwie nogi albo koniec ucha, tak nieliczni uratowani będą synowie Izraela") odniesiony do Chrystusa, który oddaje swoje życie za owce $(\mathrm{J} 10,11)$ 
TeOdoret z Cyru (PG 81, 1664-1708)

Komentarz do Amosa pisze jako biskup Cyru, wkrótce po napisaniu Komentarza do Psalmów. Jeśli Komentarz do Psalmów datujemy na lata 441-449, ${ }^{1}$ to Komentarz do Amosa powstałby ok. 450 r.

We wstępie Teodoret podkreśla cel (skopos) księgi, w świetle którego będzie komentował poszczególne wersety: jest nim troskliwość (kêdemonia, synonim opatrzności), z jaką Bóg opiekuje się Izraelem.

Jest to wybitnie komentarz historyczny, mający jedynie dwa odniesienia chrystologiczne:

- Am 7,14: Wzmianka o „nacinaniu sykomory” ewokuje krótkie nawiązanie do Zacheusza, który wspiął się na sykomorę, lecz bez teologicznego pogłębienia tematu;

- Am 9,11: „Podniosę szałas Dawidowy” - są to słowa proroctwa, które wypełniły się we wcieleniu Jezusa.

Hezychiusz z Jerozolimy (PG 93, 1349-1352)

Hezychiusz był mnichem i prezbiterem żyjącym na przełomie IV i V w., prawdopodobnie wyznawcą monofizytyzmu. Sześć nieopublikowanych rękopisów przechowywanych w Rzymie, Paryżu i Moskwie zawiera cytaty z jego komentarzy do Proroków Mniejszych, które wskazują na wybitnie aleksandryjskie podejście egzegetyczne.

W serii „Patrologia Graeca” opublikowano jedynie kefalaia, czyli nagłówki stanowiące śródtytuły poszczególnych perykop zaginionego komentarza. Wynika z nich jednoznaczne odniesienie chrystologiczne: kary, jakie mają dotknąć Izraela i Judę, powodowane są przyszłym odrzuceniem Jezusa, a zniszczenie świątyni jest skutkiem tego, że w przyszłości zniszczą świątynię, jaką jest Jego Ciało. Natomiast ostatnia perykopa, dotycząca odnowy mesjańskiej (Am 9,11-15), nawiązuje do nawrócenia i wiary Izraela przy końcu czasów.

1 Por. M. B r o k, Touchant la date du commentaire sur le psautier de Théodoret de Cyr, RHE 44/1949, s. 552-556. 
Komentarze łacińskie

Hieronim ze Strydonu (CCL 76/1, wyd. M. Adriaen, 1969, 211-348)

Komentarze Hieronima do poszczególnych Proroków Mniejszych pisane były w różnych okresach jego życia. Komentarz do Amosa (wraz z Za, Ma, Oz i Jl) należy do najpóźniejszych i powstał w 406 r., już podczas pobytu Hieronima w klasztorze w Betlejem.

Komentarz poprzedza krótki wstęp historyczny. Każdy werset najpierw został przełożony z hebrajskiego, następnie z greckiego tłumaczenia Septuaginty. Następnie Hieronim podaje wyjaśnienia kwestii filologicznych, geograficznych, kontekstu historycznego oraz rozwinięcia symboliczne: np. Damaszek symbolizuje heretyków (Am 1,3-4) - etymologicznie „ci, którzy piją krew (dam)” (s.228).

Klucz hermeneutyczny przyjęty przez Hieronima jest następujący: Juda i Jerozolima (Królestwo południowe) oznaczają Kościół, zaś Izrael (Samaria, Królestwo północne) - heretyków, którzy oddzielili się od Kościoła. Również mowa przeciw Judzie Am 2,4-5 jest napomnieniem skierowanym do tych ludzi Kościoła, którzy „wzgardzili Prawem Boga, nie wypełniali Jego przykazań i hołdowali swoim nałogom i grzechom". ${ }^{2}$

Julian z Eklanum (Pseudo-Rufin z Akwilei) (PL 21,1057-1104)

Autorem kolejnego komentarza jest pelagianin, adresat pism Augustyna Contra Iulianum. Na skutek potępienia pelagianizmu przez papieża Zosyma opuszcza w 418 r. swoją diecezję Eklanum (koło Benewentu w Italii) i udaje się na wschód, następnie na Sycylię. Umiera w 454 r. opuszczony i zapomniany przez wszystkich. Jego dzieła egzegetyczne, Komentarz do Proroków Mniejszych i Komentarz do Hioba, są trudne do datowania.

Komentarz do Księgi Amosa ma charakter historyczny, z licznymi odwołaniami do innych ksiąg prorockich. Pojawiają się oszczędne

2 „Legem Dei contempserit, et eius mandata non fecerit et unusquisque adorans vitia sua atque peccata", s. 232. 
interpretacje chrystologiczne i eklezjalne, nacisk jednak jest położony na sens dosłowny.

\section{Wybrane motywy Księgi Amosa rozwijane w tradycji Kościoła w kluczu symboliki literackiej}

Kobiety ciężarne jako symbol niedojrzałych chrześcijan

Am 1,13: „Tak mówi Pan: Z powodu trzech występków synów Amnona i z powodu czterech nie odwrócę tego wyroku, gdyż rozcinał brzemienne niewiasty Gileadu, by rozszerzyć swoje granice".

Kobiety ciężarne Gileadu w interpretacji Hieronima (Komentarz do Amosa, ad locum), którą podejmuje również Garnier z Langres, ${ }^{3}$ symbolizują niedojrzałych chrześcijan, których wiara jest chwiejna. Natomiast synowie Amnona oznaczają heretyków, którzy, wykorzystując słabą wiarę początkujących chrześcijan, pozyskują ich w swoje szeregi, niszcząc tym samym Boże życie w ich sercach, zanim jeszcze osiągnęło dojrzałość. Interpretacja wpisuje się w kontekst sporów doktrynalnych pierwszych wieków chrześcijaństwa i podkreśla potrzebę szczególnej troski ze strony Kościoła o pielęgnowanie i wzrost wiary u poszczególnych chrześcijan, jak również zagrożenie ze strony heterodoksyjnych doktryn.

Trąba jako symbol głoszenia słowa Bożego

Am 3,6: „Czyż dmie się w trąbę w mieście, a lud się nie przelęknie? Czyż zdarza się w mieście nieszczęście, by Pan tego nie sprawił?”

Motyw literacki trąby występujący w wersecie interpretowany jest przez główne nurt tradycji jako symbol głoszenia słowa Bożego. Komentatorzy odczytują go podobnie, jak w historii o zdobyciu Jerycha: ${ }^{4}$

3 Garnier z Langres, Allegoriae totius Scripturae, Galaad, PL 112, 939C.

4 Szerzej na temat symboliki trąby w starożytnym chrześcijaństwie, zob. K. B a r d s k i, W kręgu symboli biblijnych, Kraków 2010, s. 73-75. 
kapłani oraz uprawnieni głosiciele słowa Bożego powołani są do tego, by zwiastować Ewangelię i głosić naukę, której celem jest upomnienie. Podobnie jak potężny dźwięk trąby, ich głoszenie ma się dokonywać z mocą i odwagą. Lęk ze strony ludu nie jest spowodowany samym dźwiękiem trąby, lecz uświadomieniem sobie własnej grzeszności oraz perspektywą sądu Bożego. Z tego rodzi się potrzeba nawrócenia: „nieszczęście", które Pan sprawia, ma charakter naprawczy, podobnie jak zburzenie murów Jerycha (oznaczającego zatwardziałe ludzkie serce) umożliwiło dotarcie do jego wnętrza słowa Dobrej Nowiny.

\section{Lew jako symbol Boga}

Am 3,8: „Gdy lew zaryczy, któż się nie ulęknie? Gdy Pan Bóg przemówi, któż nie będzie prorokować”.

Lew, uważany już w starożytności za władcę świata zwierzęcego, w symbolice biblijnej ma charakter ambiwalentny. W niektórych tekstach symbolizuje Boga i Mesjasza (Lew z pokolenia Judy), w innych zaś szatana (władcę tego świata), np. „Jak lew ryczący krąży szukając kogo pożreć" (1P 5,8).

Paraleliczna budowa wersetu wyraźnie wskazuje na boską symbolikę lwa. Ponadto kontekst sugeruje dalsze konotację. Motywem wiodącym jest tutaj ryczenie lwa, które paralelnie zostało odniesione do Boga, który „,przemówi”. Z perspektywy dziejów zbawienia momentem, w którym Bóg wypowiedział w pełni swoje słowo jest wcielenie Chrystusa. To On jest Słowem, które było na początku i On jest królem nad królami, dlatego też motyw lwa pojawiający się w tym wersecie jest interpretowany jako symbol panującego Chrystusa.

Krowy Baszanu jako bogacze żerujący na krzywdzie ubogich

Am 4,1: „Słuchajcie słowa tego, krowy Baszanu, które mieszkacie na górach Samarii: uciskacie biednych, gnębicie ubogich, mówicie do mężów swoich: «Przynieś, a będziemy pili!»»"

Również symbol krowy ma ambiwalentne odniesienia w interpretacji tekstu biblijnego. Krowa, jako zwierzę dające mleko, doczekała 
się pozytywnych interpretacji, mianowicie symbolizuje głosicieli słowa Bożego, którzy w myśl słów św. Pawła $(1$ Kor 3,2) karmią wiernych mlekiem Bożej nauki. ${ }^{5}$

Jednak w przytoczonym tutaj wersecie „krowy Baszanu” mają wydźwięk wybitnie pejoratywny. Już na poziomie sensu historycznego wskazują na możnych Izraela, którzy wykorzystują i uciskają ubogich. To znaczenie symboliczne podkreśla Garnier z Langres ${ }^{6}$ chociaż wcześniejsza interpretacja, którą znajdujemy u Hieronima (Komentarz do Amosa, ad locum), postrzega w „krowach Baszanu” również heretyków. Hieronim opiera tę interpretację na swoistej etymologii. Wprawdzie w swoim tłumaczeniu z hebrajskiego „krowy Baszanu” odczytuje jako vaccae pingues (,krowy tłuste”), jednak w dalszym komentarzu słowo „Baszan” interpretuje jako oznaczające „hańbę”, przypuszczalnie doszukując się w tej nazwie hebrajskiego rdzenia czasownikowego bet-waw-szin, oznaczającego ,wstyd, hańbę".

Clavis Pseudo-Melitona z Sardes, powołując się na ten werset biblijny rozszerza pierwotne odniesienie historyczne, widząc w „krowach Baszanu" nie tylko książęta Izraela, ale wszystkich ludzi bogatych, którzy żerują na nędzy innych i wykorzystują ich.?

Łoża z kości słoniowej jako symbol doczesnych uciech

Am 6,4: „Leżą na łożach z kości słoniowej i wylegują się na dywanach; jedzą oni jagnięta z trzody i cielęta ze środka obory".

Również ponaddosłowna symbolika łoża w interpretacji Pseudo-Melitona stanowi rozwinięcie sensu dosłownego. ${ }^{8} \mathrm{~W}$ kontekście

$5 \quad$ Szerzej o symbolice krowy zob. t e n ż e, Kapłaństwo ministerialne w biblijnej symbolice teriomorficznej starożytności i średniowiecza, Verbum Vitae 17/2010, s. 303-314.

6 G a r n ie r z L a n g re s, Allegoriae totius Scripturae 1072A.

7 Ps-Meliton z S a rdes, Clavis, vaccae, 12,1,45.

8 Tamże, lectus, 9,3,50. U Ps-Melitona łoże symbolizuje również pokój ducha i kontemplację (na podstawie Pnp 3,1 i Mt 24,40), tajemnicę Kościoła, w którym przebywa Chrystus (Pnp 3,7), ludzkie ciało wraz z jego słabościami (Ps 6,7; 40,4), 
historycznym motyw łoża ilustruje styl życia możnych Izraela, którzy w poprzednio omawianym przez nas wersecie przyrównani zostali do „krów Baszanu”. W tym natomiast wersecie pozycja horyzontalna oraz miękkość posłania symbolizuje życie w doczesnych dostatkach, z poniechaniem dzieł miłosierdzia wobec innych, jakie charakteryzuje ludzi bogatych nie troszczących się o bliźnich.

Wielka Otchłań jako symbol przewrotnych serc grzeszników

Am 7,4: „To mi ukazał Pan Bóg: Pan Bóg powołał jako narzędzie sądu ogień i strawił Wielką Otchłań, i strawił dział Pański”.

Wprawdzie historyczne odniesienie wersetu sugeruje jego interpretację w kontekście najazdu babilońskiego i zburzenia Jerozolimy, jednak tekst nie podsuwa jednoznacznej odpowiedzi na pytanie, czym jest ów tehom rabba (Wielka Otchłań). Dlatego tradycja starożytna i średniowieczna doszukuje się to różnych znaczeń. Dla Hieronima (Komentarz do Amosa, ad loc.) określenie to obejmuje wszelki rodzaj grzeszników (omnia genera peccatorum), natomiast Pseudo-Meliton widzi tu raczej mroczną głębię przewrotnych serc ludzi grzesznych i zestawia ten werset z Hi 28,14 (otchłań, która nie zawiera w sobie mądrości). To, co łączy obie interpretacje, to eschatologiczny klucz interpretacyjny: zarówno grzesznicy, jak i przewrotne zamysły ich serc, doznają unicestwienia $\mathrm{w}$ dniu sądu.

Kosz dojrzałych owoców jako symbol słodyczy i ciężaru grzechów

Am 8,2: „I zapytał: «Co ty widzisz, Amosie?» Odpowiedziałem: «Kosz dojrzałych owoców». Rzekł Pan do mnie: «Dojrzał do kary lud mój izraelski. Nie będę już dłużej go oszczędzał»".

Symboliczne odniesienie „kosza dojrzałych owoców” do grzechów Izraela nie wymagało procesu alegoryzacji, gdyż mamy tu do czynienia z metaforą już na poziomie sensu historycznego. Tradycja

nęcącą a kłamliwą doktrynę heretyków (Prz 7,16) lub udrękę, jaka czeka grzesznika w przyszłym życiu (Ap 2,22). 
Kościoła rozszerza jednak zakres tej symboliki do wszystkich grzechów ludzkich, które - w oparciu o skojarzenie reminiscencyjne z Mt 7,17 („Każde dobre drzewo wydaje dobre owoce, a złe drzewo wydaje złe owoce") - obejmują czyny nieprawe wszystkich, którzy porównani zostali do ,złego drzewa”.

Użyte w przekładzie łacińskim słowo poma, poza ogólnym znaczeniem „owoc”, szczegółowo może nawiązywać do „jabłka”, które zwłaszcza w symbolice zbudowanej na występowaniu tego terminu w Pieśni nad Pieśniami, ma konotacje pozytywne. ${ }^{9}$ Dlatego też Pseudo-Meliton rozwija symbolikę wersetu, pisząc o zgubnej słodyczy grzechu..$^{10}$

\section{Zachód słońca jako symbol grzesznego życia}

Am 8,9: „Owego dnia - wyrocznia Pana Boga - zajdzie słońce w południe i w dzień świetlany zaciemnię ziemię".

Eschatologiczna wizja słońca zachodzącego wbrew prawom natury jednoznacznie wpisuje się w szerszą, negatywną symbolikę ciemności. Tym bardziej że „zachód słońca” w kontekście symboliki chrystologicznej oznacza nieobecność Chrystusa, a w konsekwencji - panowanie Szatana. Tradycja nie tylko odczytuje ten werset w kluczu eschatologicznym, lecz postrzega w nim również aluzję do powtarzających się w dziejach świata sytuacji, kiedy ciemność triumfuje nad światłością.

Spośród tekstów nowotestamentowych szczególny związek ma ten werset z apokaliptyczną wypowiedzią Jezusa z Mk 13,24 („Słońce się zaćmi i księżyc nie da swego blasku”) oraz z godziną ciemności, jaka nastała wraz ze śmiercią Jezusa na krzyżu Łk 23,45 (,,Słońce się zaćmiło i zasłona przybytku rozdarła się przez środek”).

9 Zob. G a r n i e r z L a n g re s, Allegoriae totius Scripturae, 1030B-1031A. Podobnie Eucheriusz z Lyonu.

10 P s - Meliton z S a rdes, Clavis, 6,2,71. 
Dziewice jako symbol bezowocnej wstrzemięźliwości

Am 8,13: „W dzień ten pomdleją z pragnienia piękne dziewice i młodzieńcy".

Wprawdzie tradycja chrześcijańska zarówno w starożytności jak i w średniowieczu wysoko ceniła dziewictwo, jednak negatywny kontekst eschatologiczny wersetu (podobnie jak w Am 5,2) sugeruje, że dziewictwo ma tu znaczenie zgoła odwrotne. W Clavisie czytamy, że werset ten można symbolicznie odnosić do tych, „którzy zachowują wstrzemięźliwość nie ze względu na nagrodę wieczną, lecz dla ludzkiej pochwały" i zostali w Mt 25,1 porównani do panien nieroztropnych. ${ }^{11}$ Można do tego dodać również wyjaśnienie, jakie Garnier z Langres przedstawia odnośnie do Am 5,2, że mianowicie dziewictwo, o jakim jest tutaj mowa, kojarzy się z jałowością i bezpłodnością. ${ }^{12}$

Sito jako symbol eschatologicznego sądu

Am 9,9: „Gdyż oto Ja rozkażę i przesieję pomiędzy wszystkimi narodami dom Izraela, jak się przetakiem przesiewa, a żadne ziarnko nie upada na ziemię".

Jednym z charakterystycznych motywów apokaliptycznych jest rozdzielenie sprawiedliwych od grzeszników. W przypowieściach Jezusa zostało to zobrazowane w przeciwstawieniu jęczmienia i chwastów (Mt 13,30), pszenicy i plew (Mt 3,12), owiec i kozłów (Mt 25,32). $\mathrm{Z}$ tej perspektywy odczytywany był również werset Am 9,9, który tradycja chrześcijańska nie tylko odnosiła do „domu Izraela”, jak sugeruje historyczny kontekst, lecz do wszystkich grzeszników.

11 Tamże, 8,3,14.

12 Garnier z L a ng re s, Allegoriae totius Scripturae, 1080C. 
Winnice jako symbol dobrych czynów

Am 9,14: „Uwolnię z niewoli lud mój izraelski - odbudują miasta zburzone i będą w nich mieszkać; zasadzą winnice i pić będą wino; założą ogrody i będą jedli z nich owoce".

Perspektywa odnowy przedstawiona w ostatniej perykopie Księgi Amosa (Am 9,11-15) odczytywana była w tradycji chrześcijańskiej jako zapowiedź mesjańska, która wypełniła się wraz z wcieleniem Chrystusa. Pierwszy werset perykopy (Am 9,11: „Podniosę szałas Dawidowy") jednoznacznie odnoszony był do potomka Dawida, jakim był Jezus, zaś odnowa mesjańska zyskała wymiar alegorii eklezjalnej. W tym kontekście symbolika „owoców”, podobnie jak „winnicy” zyskuje walor pozytywny, jako wypełnianie dobrych czynów dzięki łasce, którą obdarzył nas Mesjasz.

\section{Szczególny przypadek Am 8,11}

Na tle patrystycznej interpretacji Księgi Amosa w sposób szczególny wyróżnia się werset Am 8,11. Bez wątpienia jest on najczęściej cytowanym wersetem księgi. Pojawia się w różnych tekstach starożytnych, nie tylko w komentarzach do księgi. W ramach przeprowadzonej kwerendy dotarliśmy do ponad 50 interpretacji zawartych w dziełach patrystycznych. Ze względu na objętość artykułu ograniczymy się w tym miejscu do Ojców greckich, z nadzieją na opublikowanie oddzielnego artykułu poświęconego interpretacji łacińskiej.

W przekładzie Am 8,11 z hebrajskiego czytamy: „Oto nadejdą dni - wyrocznia Pana Boga - gdy ześlę głód na ziemię, nie głód chleba ani pragnienie wody, lecz głód słuchania słów Pańskich". Werset wchodzi w skład większej jednostki tematycznej obejmującej Am 8,9-14, której wątkiem przewodnim jest idea Dnia Pańskiego (,ów dzień"), w którym kara dosięgnie nieprawych w Izraelu. Jednostka ta składa się z trzech mniejszych perykop: 9-10 (ciemność i żałoba), 11-12 (głód słów Pańskich) oraz 13-14 (śmierć z pragnienia). Literacki kontekst wersetu, zwłaszcza uwzględniając Am 8,12 („Wtedy błąkać się będą od morza do morza, z północy na wschód będą krążyli, by 
znaleźć słowo Pańskie, lecz go nie znajdą”), sugeruje nie tyle „zesłanie głodu" w sensie wzbudzenia potrzeby słuchania słów Boga, ile raczej dopuszczenie takiej sytuacji, w której słowo Boże stanie się niedostępne lub nieobecne.

Podstawową, mianowicie chrystologiczną interpretację wersetu znajdujemy już u Orygenesa. W Homiliach o Ewangelii św. Łukasza widzi on wypełnienie się proroctwa Amosa wraz z narodzeniem Jezusa. W nawiązaniu do Łk 3,23 (,Sam zaś Jezus rozpoczynając swoją działalność miał lat około trzydziestu. Był, jak mniemano, synem Józefa, syna Helego"), Orygenes rozwija wątek 30 lat. Przypomina historię Józefa z Rdz 41,46 (Józef miał lat trzydzieści, gdy stanął przed faraonem, królem egipskim. Józef, wyszedłszy od faraona, objeżdżał cały kraj). Następnie łączy te dwa wersety: „Ten drugi Józef (Jezus) zgromadził inną pszenicę aniżeli pierwszy Józef w Egipcie: zgromadził prawdziwą, niebieską pszenicę, aby nagromadziwszy ją w latach urodzaju miał co rozdawać, gdy głód spadł na Egipt", 13 po czym następuje cytat Am 8,11.

W tym samym dziele Orygenes jeszcze raz nawiązuje do Am 8,11, również w sensie chrystologicznym oraz stosując pośrednią aktualizację. ${ }^{14}$ Punktem wyjścia jest tekst Łk 4,25 („Naprawdę, mówię wam: Wiele wdów było w Izraelu za czasów Eliasza, kiedy niebo pozostawało zamknięte przez trzy lata i sześć miesięcy, tak że wielki głód panował w całym kraju"). Wydarzenie z historii Eliasza, podobnie jak proroctwo Amosa, zapowiada Chrystusa i głód słowa, który On zaspokaja. Jednak w dalszej części komentarza Orygenes dodaje: „Ty byłeś wdową w Sarepta, w kraju Sydonu”, tym samym odnosi również proroctwo Amosa do aktualnego kontekstu słuchaczy homilii.

Kolejną aktualizację wersetu znajdujemy w Komentarzu do Ewangelii św. Jana. ${ }^{15}$ Homilia dotyczy rozmowy Jezusa z Samarytanką

13 Oryge nes, Homilie o Ewangelii św. Łukasza, 28,5, PSP 36, Warszawa 1986, s.112

14 Tamże, 33,4, s.125.

15 Te n ż e, Komentarz do Ewangelii św. Jana, 13,34, ŻMT 27, Kraków 2005, s. 320 . 
(J 4,13-54). Orygenes rozszerza kontekst do perykop ewangelicznych mówiących o głodzie i pragnieniu. Bóg nigdy nie pozostawia człowieka głodnym (Prz 10,3; wg LXX), więc interpretuje słowa Amosa jako groźbę pod adresem tych, którzy są niesprawiedliwi: „Kiedy jednak staniemy się niesprawiedliwi, ześle na ziemię głód słuchania słów Pańskich” i tu następuje cytat Am 8,11. Tym samym „głód słowa Pańskiego" jawi się jako środek naprawczy, który Bóg może stosować wobec grzeszników. ${ }^{16}$

Nie dotyczy to jednak tylko grzeszników. Bóg może zsyłać „,pragnienie słowa pańskiego" również w tym celu, by pogłębić swoją więź z człowiekiem i pomóc mu w duchowym wzroście. Rozwijając w kluczu symbolicznym motyw studni, przy której sługa Abrahama spotyka Rebekę, jako żywej wody słowa Bożego, Orygenes pisze: „Jeśli więc nie będziesz przychodził codziennie do studni, jeśli nie będziesz codziennie czerpał wody, to nie tylko nie będziesz mógł napoić innych, ale i sam zaznasz pragnienia słowa Bożego". ${ }^{17}$

Szczególną aktualizacją jest dla Orygenesa odniesienie Am 8,11 do Izraela, który nie rozpoznawszy Mesjasza, doświadcza „głodu słowa” dopóty, dopóki nie otworzy na niego swoich oczu: „Oto porzucony został lud, który jest nim «wedle ciała», leży on w głodzie i pragnieniu, doznając «nie głodu chleba, ani pragnienia wody, lecz głodu słowa Bożego», do czasu, aż otwarte zostaną oczy Synagogi". ${ }^{18}$

O ile w ujęciu Orygenesa proroctwo Amosa wypełniło się w odniesieniu do Żydów, którzy nie przyjęli Jezusa, oraz do grzeszników, to jednak - jak pisze w Komentarzu do Księgi Kapłańskiej ${ }^{19}$ - „dotychczas Bóg nie zesłał głodu na swój Kościół, nie «zesłał głodu słuchania słowa Bożego». Mamy bowiem «Chleb Żywy, który zstąpił $\mathrm{z}$ nieba» $(\mathrm{J} 4,41)$, mamy «żywą wodę tryskającą ku życiu wiecznemu» $(\mathrm{J} 4,14)$ ”. Słowa te służą wprowadzeniu pytania: „Czemu

16 Podobną interpretację podaje Orygenes w: t e n ż e, Homilie o Księdze Rodzaju 16,4, PSP 31/1, Warszawa 1984, s.150 oraz: 11,2, s. 255.

17 Tamże, 10,3, s. 109.

18 Tamże, 7,6, s. 89.

19 Te n ż e, Homilie o Księdze Kapłańskiej, PSP 31/2, Warszawa 1984, s.136. 
przy obfitości pokarmu zabijamy sami siebie głodem i pragnieniem?" Istnieje więc dla Orygenesa również inny „głód i pragnienie słowa”, które nie zostały zesłane przez Boga, lecz spowodowane ludzkim lenistwem i gnuśnością.

U Teodora z Mopswestii, podobnie jak Teodoreta z Cyru, proroctwo Amosa dotyczyło historycznej sytuacji Izraela. Pierwszy z nich, po zacytowaniu Am 8,11, kontynuuje: „W tych (słowach) oznacza [semainei] wszystko to, co podczas niewoli Babilońskiej nastanie", 20 natomiast Teodoret z Cyru stwierdza, że na wygnaniu babilońskim „błądząc i tułając się będą chodzili wkoło, szukając słowa Bożego, lecz ich pragnienie nie zostanie zaspokojone". ${ }^{21}$

Cyryl Aleksandryjski (Komentarz do Amosa, ad locum) dwustopniowo wyjaśnia omawiany przez nas werset. Najpierw prezentuje ujęcie historyczne: na wygnaniu zabraknie Izraelitom słowa prorockiego. Następnie zaś podaje interpretację chrystologiczną, poprzedzoną wprowadzeniem kai kath 'heteron de tropon, co oznacza interpretację ponaddosłowną: Odrzucając Jezusa, który jest Słowem-pokarmem (J 6,51 - „Ja jestem chlebem życia”), Żydzi będą doświadczać „głodu Słowa" zapowiedzianego przez Amosa.

Grzegorz z Nyssy w mowie do załogi statku, który przywiózł zboże z Aleksandrii do Konstantynopola, oraz pozdrowienia od patriarchy aleksandryjskiego, dokonuje następującej aktualizacji: „Leczycie także nie głód chleba i nie pragnie nie wody, w których i głodowanie nie jest wielką rzeczą, i niegłodowanie łatwą, ale głód słuchania słowa Pańskiego, który i cierpieć jest rzeczą najbardziej godną politowania, i leczyć w dzisiejszych czasach bardzo trudną, ponieważ rozmnożyła się nieprawość i niewielu znajduje odpowiednich na nią lekarzy". ${ }^{22}$

Spośród nawiązań Jana Chryzostoma do Am 8,11 na uwagę zasługuje homilia, która dotyczy pierwszej perykopy Ewangelii Mateusza

20 Te o d or z Mops we s t i i, Commentarius in Amos, ad loc., PG 66,296B.

21 Te o d o r e t z C y r u, Commentarius in Amos, ad loc., PG 81,1701D.

22 Grzegor z z Nys s y, Mowa 34 do przybyszów z Egiptu, 2, w: t e n że, Mowy wybrane, Warszawa 1967, s. 396. 
(Genealogia Jezusa). Autor porusza ogólnie temat potrzeby słuchania słowa Bożego oraz podejmuje aktualizację w odniesieniu do słuchacza. Po zacytowaniu Am 8,11 stawia pytanie: „Cóż mogłoby być gorsze niż to, gdybyś sam dobrowolnie sprowadzał na siebie to, czym Bóg zagroził jako karą, skazując w ten sposób swoją duszę na jakiś rodzaj ciężkiego głodu i czyniąc z niej istotę najsłabszą w świecie". ${ }^{23}$ Natomiast w Liście do Olimpii - poza historycznym odniesieniem do Izraela - znajdujemy próbę bardzo zindywidualizowanego odniesienia wersetu do tęsknoty za słowem Bożym z ust biskupa, gdy Jan Chryzostom cytuje fragment listu adresatki: „Jesteś oddalona ode mnie i mówisz wszystkim: «nie mogę usłyszeć tego głosu, cieszyć się pouczeniami, cierpię udręki głodu; czym Bóg zagroził niegdyś Żydom, teraz ja muszę to znosić. Nie jest to głód chleba, ani pragnienie wody, lecz głód Bożej nauki»»" ${ }^{24}$

Podsumowując rozliczne interpretacje patrystyczne Am 8,11, przychodzi na myśl tradycyjny czterowiersz Augustyna z Dacji, przywołany w Katechizmie Kościoła Katolickiego (118), przedstawiający cztery sensy tekstu biblijnego. Najpierw sens dosłowny, jakim jest wypełnienie się proroctwa podczas niewoli babilońskiej (Teodor z Mopswestii, Teodoret z Cyru). Drugi jest sens chrystologiczny: wypełnienie w Chrystusie, który odnajdujemy przede wszystkim w dziełach Orygenesa. Trzeci, sens moralny, pojawia się głównie w aktualizacjach w odniesieniu do słuchaczy lub czytelników. Będzie to z jednej strony aktualizacja pozytywna, w myśl której głód słowa jawi się jako pragnienie słuchania słowa, tęsknota za nim stymulująca zarówno do codziennej lektury Biblii (Orygenes), jak i do troski o głoszenie słowa Bożego innym w dziele ewangelizacji (Augustyn). $\mathrm{Z}$ drugiej zaś strony aktualizacja negatywna - cierpienie z powodu głodu słowa, który nie jest zaspokojony z winy odbiorcy (grzesznicy Grzegorz z Nyssy; Izrael - Cyryl Aleksandryjski, Orygenes), często

$23 \mathrm{~J}$ a n Chryzos to m, Homilie na Ewangelię św. Mateusza 2,6 ŹMT 18, Kraków 2003, s.37.

24 Te n ż e, List 2 do Olimpii, 11, PSP 13,273. 
spowodowane własnymi zaniedbaniami i lenistwem. Po czwarte, mamy odniesienie eschatologiczne, które w sposób szczególny pojawi się u Augustyna, mniej zaś widoczne jest w tradycji greckiej.

ks. Krzysztof BARDSKI 